\title{
Aplikasi Label Pintar Edible dari Ekstrak Antosianin Ubi Jalar Ungu (Ipamoea Batatas L.) untuk Monitoring Kesegaran Sayuran Cabai Hijau (Capsicum Annuum L.)
}

\section{(Application of Smart Label Edible From Anthocyanin Sweet Potatoes (Ipomoea Batatas L.) Extract for Monitoring Freshness of Green Chilli (Capsicum Annuum L.)}

\author{
Aissa Dinar Yanuariski, Bambang Kuswandi, Ari Satia Nugraha \\ Jl. Kalimantan 37, Jember 68121 \\ Fakultas Farmasi Universitas Jember \\ e-mail korespondensi: aissadinary@yahoo.co.id
}

\begin{abstract}
Vegetable products are foods that are popular with many people. One vegetable product such as green chili is a vegetable commodity that cannot be abandoned by society in daily life. This was followed by demands for quality of green chili products. so that an analytical tool is needed that can analyze the freshness of green chili easily and practically. This study aims to develop an edible freshness sensor based on anthocyanin indicators from purple sweet potato extract (Ipomoea batatas L.) with a membrane mixture of cassava starch and chitosan. The edible freshness sensor can be applied as a freshness sensor and know the freshness level of green chili with various parameters. Tests for green chili freshness test included $\mathrm{pH}$ test, weight loss, texture value, and sensory evaluation test. The color change of the edible freshness sensor was observed visually and tested using the ImageJ program to determine the mean green value. The results show the color change of the freshness sensor is dark purple when the green chili is fresh, the light purple is still fresh and the light green is no longer fresh or rotten. The mean value of the green sensor for edible freshness increased along with the decline in the quality of green chili in the packaging.
\end{abstract}

Keywords: Anthocyanin, tapioca starch, chitosan, green chilli

\begin{abstract}
Abstrak
Produk sayuran merupakan bahan pangan yang banyak digemari oleh masyarakat. Salah satu produk sayuran seperti cabai hijau merupakan suatu komoditas sayuran yang tidak dapat ditinggalkan masyarakat dalam kehidupan sehari - hari. Hal tersebut diikuti dengan tuntutan kualitas mutu produk cabai hijau. sehingga dibutuhkan suatu alat analisa yang dapat menganalisis kesegaran cabai hijau secara mudah dan praktis. Penelitian ini bertujuan untuk mengembangkan sensor kesegaran edible berbasis indikator antosianin dari ekstrak ubi jalar ungu (Ipomoea batatas L.) dengan membran campuran pati singkong dan kitosan. Sensor kesegaran edible tersebut dapat diaplikasikan sebagai sensor kesegaran dan mengetahui tingkat kesegaran cabai hijau dengan berbagai parameter. Dilakukan uji parameter kesegaran cabai hijau meliputi uji nilai $\mathrm{pH}$, susut bobot, nilai tekstur, dan uji sensory evaluation. Perubahan warna sensor kesegaran edible diamati secara visual dan diuji menggunakan program ImageJ untuk menentukan nilai mean green. Hasil menunjukkan perubahan warna sensor kesegaran yaitu ungu tua saat cabai hijau dalam keadaan segar, ungu muda masih segar dan hijau muda sudah tidak lagi segar atau busuk. Nilai mean green sensor kesegaran edible meningkat seiring dengan penurunan mutu cabai hijau dalam kemasan.
\end{abstract}

Kata Kunci: Antosianin, pati-singkong, kitosan, cabai hijau 


\section{Pendahuluan}

Sayuran dan buah segar sangat mudah rusak dan perlu penanganan dan penyimpanan yang sesuai untuk mempertahankan kualitas dan memperpanjang waktu simpan. Produk sayuran seperti cabai hijau merupakan suatu komoditas sayuran yang tidak dapat ditinggalkan masyarakat dalam kehidupan sehari - hari. Cabai dianggap penting untuk dijadikan bahan ramuan industri makanan, minuman maupun farmasi [1].

Menyimpan cabai dengan cara pengemas dan lama penyimpanan yang tepat perlu dilakukan agar kualitasnya tidak menurun drastis. Sehingga perlu disebutkan pentingnya peningkatan pemantauan waktu pembusukan atau kesegaran produk-produk tersebut dengan mudah yakni mengevaluasi kualitas produkproduk sayuran yang baru dan memastikan keamanannya selama penyimpanan dan penjualan [2]. Salah satu alternatif lain untuk mendukung masalah tersebut yaitu menggunakan kemasan cerdas (smart packaging).

$$
\text { Kemasan cerdas dapat }
$$

mengkomunikasikan kepada konsumen dan dapat dinyatakan sebagai tanda awal bagi pengguna dengan merasakan perubahan lingkungan internal dan eksternal yang ada dalam kemasan [3]. Salah satu contoh tipe kemasan cerdas yakni, indikator kesegaran merupakan alat kecil yang di desain pada film kemasan baik atau pada label kemasan.

Indikator warna berbasis $\mathrm{pH}$ sensitif dilaporkan dapat digunakan sebagai kemasan cerdas yang menjanjikan untuk menentukan metabolit mikroba untuk kesegaran produk makanan [4]. Indikator tersebut seperti bromkresol ungu, kresol merah dan bromtimol biru. Namun, penggunaan senyawa-senyawa kimia tersebut mulai dihindari karena memiliki potensi efek berbahaya bagi manusia yang bersifat karsinogenik [5] atau mutagenik [6].

Zat warna alami yang dapat digunakan sebagai alternatif indikator kolorimetri yang dinilai lebih aman, tidak toksik, mudah dipreparasi, dan ekonomis jika dibandingkan dengan pewarna sintetik. Zat warna yang dapat diekstrak dari sumber bahan alami adalah antosianin yang termasuk golongan senyawa flavonoid. Salah satu sumber antosianin yang paling murah dan banyak terdapat di Indonesia adalah ubi jalar ungu. Warna antosianin yang diekstraksi dari ubi jalar ungu $\mathrm{pH}$ rendah berwarna merah muda dan berwarna hijau sampai kuning pada $\mathrm{pH}$ tinggi, sehingga berpotensi sebagai indikator kolorimetri dalam pembuatan sensor [7]. Penggunaan indikator kolorimetri membutuhkan membran sebagai media reaksi antara reagen dan analit pada suatu pembuatan sensor. Penggunaan membran film edible yang berasal dari pati singkong dan kitosan dapat menjadi pilihan karena terbuat dari bahan alami, ramah lingkungan dan aman jika dikonsumsi [8].

Penelitian ini bertujuan untuk mengetahui apakah sensor kesegaran edible dapat diaplikasikan sebagai indikator kesegaran cabai hijau, dilakukan berbagai uji parameter tingkat kesegaran cabai hijau, serta hubungan antara perubahan warna sensor tersebut dengan berbagai parameter tingkat kesegaran cabai hijau. Hasil dari penelitian ini diharapkan mampu memberi informasi tentang tingkat kesegaran cabai hijau kepada konsumen tanpa membuka kemasan.

\section{Metode Penelitian Alat dan Bahan}

Alat yang digunakan dalam penelitian ini antara lain timbangan analitik OHAUS PA214, vial, gelas kimia, gelas ukur, pipet volume, pinset, pipet tetes, pipet volume, plat tetes, batang pengaduk, kuvet, mikropipet socorex, spektroskopi UV-Vis, pH meter EUTECH, indikator $\mathrm{pH}$ universal MERCK, blender, press kaca, oven, kamera, scanner, program imageJ.

Bahan yang digunakan dalam penelitian ini yaitu ubi jalar ungu (Ipamoea batatas L.) yang dibeli di "Pasar Tanjung" Jember, kitosan, pati singkong, etanol 96\%, aquadestilata, Polivinil Alkohol (PVA)

\section{Pembuatan Ekstrak Ubi Jalar Ungu}

Indikator ubi jalar ungu diawali dengan mengupas ubi jalar ungu lalu dipotong kecil-kecil dadu. Ekstraksi dilakukan dengan menimbang 25 gram ubi jalar ungu yang dimaserasi dengan $100 \mathrm{~mL}$ etanol $96 \%$ selama 24 jam, sehingga diperoleh konsentrasi 25\%b/v. Ekstrak ubi jalar ungu yang digunakan ditentukan kadar antosianin totalnya. Penentuan kadar antosianin total dilakukan dengan metode perbedaan $\mathrm{pH}$ ( $\mathrm{pH}$ differential) yaitu pada $\mathrm{pH} 1$ dan $\mathrm{pH} 4,5$.

\section{Pembuatan Membran Pati Singkong-Kitosan}

Ditimbang pati singkong sebanyak $3 \mathrm{~g}$ dilarutkan dengan $30 \mathrm{~mL}$ aquades dipanaskan pada suhu gelatinisasi $80^{\circ} \mathrm{C}$ disertai pengadukan hingga terbentuk gelatin. Kitosan ditimbang sebanyak $2 \mathrm{~g}$ dilarutkan bersama asam asetat $1 \%$ ad larut sebanyak $20 \mathrm{~mL}$ hingga 
terbentuk adonan kental dan berwarna coklat bening. Pati dan kitosan dicampur dan diaduk hingga homogen dan ditambahkan plastisizer gliserol sebanyak $3 \mathrm{~mL}$ hingga terbentuk larutan edible film berwarna krem. Edible film dibuat dengan menuangkan campuran ke dalam plat kaca, lalu dimasukkan ke dalam oven dengan suhu $50^{\circ} \mathrm{C}$ hingga kering ( $\left.\pm 24 \mathrm{jam}\right)$. Setelah kering film dikeluarkan dari cetakan lalu di bentuk bulat (diplong), setelah itu film siap digunakan untuk membran sensor.

\section{Fabrikasi Sensor Kesegaran Edible}

Fabrikasi sensor kesegaran edible dilakukan menggunakan membran pati singkong dan kitosan yang dipotong berbentuk lingkaran dengan diameter $7 \mathrm{~mm}$. Pengimobilisasian dilakukan menggunakan teknik adsorpsi pada ekstrak ubi jalar ungu yang telah diimobilisasi dengan teknik entrapment pada PVA 1\% dengan perbandingan ekstrak dan PVA $1: 3$ selama 90 menit.

\section{Morfologi Membran Film Edible}

Morfologi permukaan membran film edible dilihat menggunakan scanning electron microscopy (SEM), baik membran yang belum diimobilisasi dengan indikator ekstrak ubi ungu maupun yang sudah diimobilisasikan.

\section{Label Pintar Sebagai Sensor Kesegaran Edible}

Dibuat desain label seperti pada gambar 1 . Label yang disertai freshness sign diletakkan pada bagian dalam kemasan cabai hijau untuk mengetahui tingkat kesegarannya.

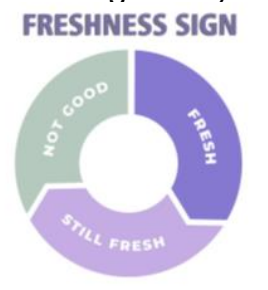

Gambar 1. Desain Sensor Kesegaran

\begin{abstract}
Analisis Perubahan Warna Sensor Kesegaran Edible

Pengamatan perubahan warna sensor kesegaran edible dilakukan secara visual dan menggunakan software ImageJ untuk mengetahui nilai mean green. Pengambilan gambar dilakukan menggunakan scanner.
\end{abstract}

\section{Uji Tekstur}

Tekstur cabai hijau diukur dengan menggunakan rheotex. Pengukuran dilakukan dengan menusukkan jarum rheotex sedalam 3 $\mathrm{mm}$ pada cabai hijau Kemudian menekan tombol start sampai terdengar bunyi yang merupakan tanda selesai. Angka yang ditunjukkan jarum rheotex (g) merupakan nilai tekstur dari cabai hijau. Pengukuran dilakukan di 5 titik yang berbeda pada setiap sampel.

\section{\% Susut Bobot}

Pengukuran susut bobot dari cabai hijau dilakukan padaapengamatan hari ke 0 (b0) dan setiap pengamatan (bt) yang dilakukan setiap hari dengan menggunakan timbangan analitik.

$\%$ Susut Bobot

Keterangan :

b0 = bobot awal cabai hijau

bt = bobot akhir cabai hijau

Hasil susut bobot didapat dengan membandingkan bobot awal dan bobot akhir. Susut bobot cabai hijau dinyatakan dengan persen (\%) [9].

\section{Uji $p H$}

Sebanyak 1 gram sampel dihancurkan dalam mortir dan dilarutkan dalam $20 \mathrm{~mL}$ aquades dan dihomogenkan. Kemudian diukur dengan $\mathrm{pH}$ meter yang sebelumnya telah dikalibrasi dengan buffer standar 4, 7, dan 10.

\section{Uji sensory evaluation}

Pada uji ini dilakukan penilaian pada kenampakan warna dan bau. 10 orang panelis akan memberikan nilai pada sampel yang diamati. Semakin segar cabai hijau nilainya akan semakin tinggi, nilai yang diberikan berkisar 3-1.

\section{Hasil dan Pembahasan Pembuatan Ekstrak Ubi Ungu}

Berdasarkan hasil penelitian ini diperoleh rata-rata konsentrasi antosianin total ekuivalen sianidin-3-glikosida dari ekstrak ubi jalar ungu yang digunakan sebesar 35,070 mg/L.

\section{Pembuatan Membran Film Edible}

Membran kering yang dihasilkan memiliki ketebalan 0,27 $\mathrm{mm}$, kemudian dipotong dengan diameter $7 \mathrm{~mm}$. Membran film edible yang siap dipakai dapat dilihat pada gambar 2 .

Gambar 2. Membran film edible

\section{Fabrikasi Sensor Kesegaran Edible \\ Fabrikasi dilakukan dengan mengimobilisasikan ekstrak ubi jalar ungu pada}


membran film. Hasil fabrikasi dapat dilihat pada gambar 3.

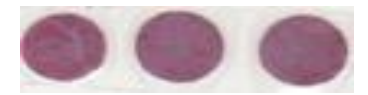

Gambar 3. Membran film yang telah diimobilisasi

Morfologi Permukaan Membran Film Edible

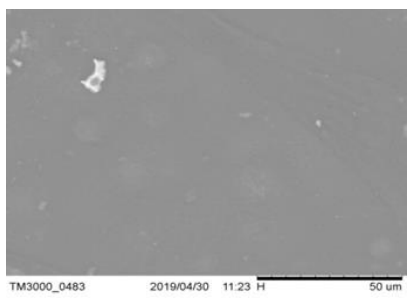

(a) (b)

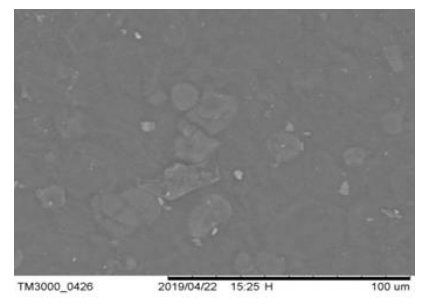

Gambar 3. Mortologi permukaan membran film edible

Pada gambar 4 adalah karakterisasi morfologi membran yang dihasilkan dengan menggunakan SEM (a) merupakan struktur permukaan membran film campuran kitosan dan pati singkong sebelum diimobilisasi menunjukan permukaan yang homogen. Pada gambar (b) ketika diimobilisasi dengan indikator ubi jalar ungu, permukaan tampak lebih kasar dikarenakan adanya penyerapan zat antosianin ubi jalar ungu oleh membran film.

\section{Perubahan Warna Sensor Kesegaran Edible}

Sensor kesegaran edible pada cabai hijau yang disimpan pada suhu ruang selama 7 hari dapat diamati perubahan warna secara visual pada gambar 5. Membran kemudian discan dan dianalisis menggunakan software ImageJ. Pada tabel 1 dapat dilihat adanya peningkatan nilai mean green seiring lamanya waktu penyimpanan.

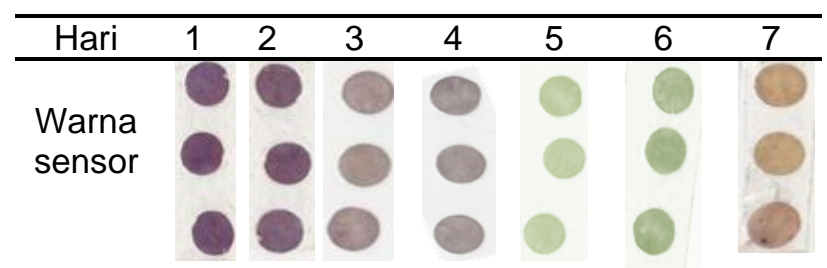

Gambar 5. Perubahan warna sensor kesegaran edible pada penyimpanan suhu ruang
Tabel 1. Nilai mean green penyimpanan suhu

\begin{tabular}{cc} 
ruang & \\
\hline Hari & Mean green \pm SD \\
\hline 1 & $84,577 \pm 0,818$ \\
2 & $100,939 \pm 3,008$ \\
3 & $130,588 \pm 2,176$ \\
4 & $141,912 \pm 3,290$ \\
5 & $149,243 \pm 0,578$ \\
6 & $152,617 \pm 3,781$ \\
7 & $157,329 \pm 2,063$ \\
\hline
\end{tabular}

\section{Uji Tekstur}

Uji tekstur dilakukan menggunakan alat Rheotex dengan kedalaman jarum $3 \mathrm{~mm}$. Hasil uji tekstur dapat dilihat pada tabel 2.

Tabel 2. Hasil Uji Tekstur

\begin{tabular}{cc}
\hline Hari & $\begin{array}{c}\text { Mean } \pm \text { SD } \\
(\mathrm{g} / 3 \mathrm{~mm})\end{array}$ \\
\hline 1 & $298 / 3 \pm 5,132$ \\
2 & $220 / 3 \pm 5,508$ \\
3 & $186 / 3 \pm 8,083$ \\
4 & $66 / 3 \pm 9,074$ \\
5 & $40 / 3 \pm 4,509$ \\
6 & $31 / 3 \pm 3,606$ \\
7 & $19 / 3 \pm 2,000$ \\
\hline
\end{tabular}

\section{$\%$ Susut Bobot}

Pengukuran \% susut bobot menggunakan timbangan analitik dengan 3 kali replikasi.

Tabel 3. Hasil Uji Susut Bobot

\begin{tabular}{cc}
\hline Hari & \% Susut bobot \\
\hline 1 & $0,000 \%$ \\
2 & $1,417 \%$ \\
3 & $3,251 \%$ \\
4 & $6,437 \%$ \\
5 & $10,858 \%$ \\
6 & $15,185 \%$ \\
7 & $20,687 \%$ \\
\hline
\end{tabular}

\section{Uji Nilai pH}

Nilai $\mathrm{pH}$ cabai hijau ditentukan menggunakan $\mathrm{pH}$ meter. Hasil pengamatan $\mathrm{pH}$ dapat dilihat pada tabel 4 .

Tabel 4.Nilai uji pH

\begin{tabular}{cc}
\hline Hari & Nilai $\mathbf{p H} \pm$ SD \\
\hline 1 & $6,14 \pm 0,006$ \\
2 & $6,40 \pm 0,027$ \\
3 & $6,56 \pm 0,006$ \\
4 & $6,90 \pm 0,007$ \\
5 & $7,56 \pm 0,093$ \\
6 & $7,84 \pm 0,026$ \\
7 & $8,22 \pm 0,004$ \\
\hline
\end{tabular}




\section{Uji organoleptis}

Uji organoleptis cabai hijau yang disimpan pada suhu ruang dilakukan dengan menyertakan 10 orang panelis menggunakan score $1-3$, pada penelitian ini hanya dilakukan pengamatan organoleptis warna dan bau. Hasil organopeltis dapat dilihat pada tabel 5 .

Tabel 5. Nilai uji organoleptis

\begin{tabular}{crl}
\hline Hari & Warna \pm SD & Bau \pm SD \\
\hline 1 & $3,000 \pm 0,000$ & $3,000 \pm 0,000$ \\
2 & $3,010 \pm 0,001$ & $3,105 \pm 0,001$ \\
3 & $3,050 \pm 0,001$ & $3,350 \pm 0,015$ \\
4 & $2,000 \pm 0,000$ & $2,000 \pm 0,000$ \\
5 & $2,130 \pm 0,001$ & $2,175 \pm 0,015$ \\
6 & $1,509 \pm 0,001$ & $1,550 \pm 0,002$ \\
7 & $1,000 \pm 0,000$ & $1,000 \pm 0,000$ \\
\hline
\end{tabular}

\section{Pembahasan}

Seiring lamanya waktu penyimpanan cabai hijau mengalami penurunan mutu baik secara fisikawi, kimiawi maupun organoleptis. Berdasarkan hasil pengamatan warna sensor kesegaran membran film edible pada kemasan cabai hijau dengan penyimpanan suhu ruang, warna sensor kesegaran membran film edible mengalami perubahan warna seiring dengan perubahan tingkat kesegaran cabai hijau seperti yang ditunjukan pada gambar 5 . Warna sensor kesegaran membran film edible berwarna ungu tua pada saat cabai hijau segar, berwarna ungu muda saat masih segar, dan berwarna hijau muda saat sudah busuk atau tidak dapat dikonsumsi.

Nilai cabai hijau putih mengalami penurunan selama penyimpanan pada suhu ruang. Penurunan nilai tekstur menandakan adanya penurunan mutu cabai hijau itu sendiri. Bahwa ketika air menguap dari jaringan buah, tekanan turgor menurun dan sel-sel mulai menyusut dan rusak sehingga buah kehilangan kesegarannya [9].

Susut bobot berkaitan dengan proses respirasi yang menyebabkan cabai hijau mengakami penurunan kadar air. Pada suhu ruang terjadi adanya proses transpirasi yang masih berlangsung. Apabila transpirasi tetap berlangsung, maka buah menjadi keriput dan gampang busuk. Hal ini disebabkan oleh suhu penyimpanan yang optimum atau dalam keadaan suhu ruang dapat menyebabkan proses transpirasi semakin meningkat dimana laju kehilangan air meningkat sehingga susut bobot cabai hijau meningkat [10].
Hasil penelitian parameter fisikawi, kimiawi, dan organoleptis menunjukkan cabai hijau sudah tidak layak konsumsi saat hari ke-5 pada penyimpanan suhu ruang. Pada hari ke-5 cabai hijau sudah tidak layak dikonsumsi dengan nilai $\%$ susut bobot sebesar $10,858 \%$ dan nilai $\mathrm{pH}$ $7,56 \pm 0,093$. Selain itu, nilai tekstur pada hari ke5 mengalami penurunan hingga $40 \mathrm{~g} / 3 \mathrm{~mm} \pm 4,509$ serta hasil pengamatan organoleptis bau dan warna memiliki nilai kurang dari 2 yang menandakan cabai hijau sudah tidak layak dikonsumsi.

\section{Kesimpulan}

Sensor kesegaran membran film edible berbasis antosianin ubi jnalar ungu (Ipomoea batatas L.) dengan membran film edible dari campuran kitosan dan pati singkong dapat diaplikasikan pada kemasan cabai hijau sebagai indikator kesegaran. Sensor kesegaran membran film edible berwarna ungu tua pada saat cabai hijau segar, berwarna ungu muda saat masih segar, dan berwarna hijau muda saat sudah busuk atau tidak dapat dikonsumsi. Hubungan antara perubahan warna sensor kesegaran membran film edible dan nilai mean green dengan penurunan mutu cabai hijau adalah berbanding terbalik. Nilai mean green sensor kesegaran membran film edible yang diamati menggunakan program ImageJ meningkat seiring dengan penurunan mutu cabai hijau.

\section{Daftar Pustaka}

[1] Setiadi. 2001. Bertanam Cabai. Penebar Swadaya. Jakarta

[2] Kuswandi, B. 2017. Freshness Sensors for Food Packaging.

[3] Dawange, S. P., S. K. Dash, dan S. B. Patil. 2010. Smart packaging and food industry. 29(5):31-37.

[4] Chen, H. zhi, M. Zhang, B. Bhandari, dan Z. Guo. 2018. Applicability of a colorimetric indicator label for monitoring freshness of fresh-cut green bell pepper. Postharvest Biology and Technology. 140(November 2017):85-92

[5] Srivastava, S., R. Sinha, dan D. Roy, Toxicological effects of malachite green. Aquatic Toxicology. 66: 319-329.

[6] X. Zhang, S. Lu, and X. Chen, "A visual $\mathrm{pH}$ sensing film using natural dyes from Bauhinia blakeana Dunn," Sensors 
Actuators, B Chem., vol. 198, pp. 268-273, 2014.

[7] I. Choi, J. Y. Lee, M. Lacroix, and J. Han, "Intelligent $\mathrm{pH}$ indicator film composed of agar/potato starch and anthocyanin extracts from purple sweet potato," Food Chem., vol. 218, pp. 122-128, 2017.

[8] Bangyekan, C., D. Aht-ong, dan K. Srikulkit. 2006. Preparation and properties evaluation of chitosan-coated cassava starch films. 63:61-71.

[9] Trenggono dan Sutardi. 1989. Biokimia dan Teknologi Pasca Panen. Pusat Antar Universitas Pangan dan Gizi UGM Yogyakarta.

[10] Rochayat, Y. V.R Munika 2015. Respon kualitas dan ketahanan simpan cabai hijau (Capsicum annuum L.) dengan penggunaan jenis bahan pengemas dan tingkat kematangan buah. Jurnal Kultivasi Vol. 14(1) Maret 2015 